\title{
C-X-C Chemokine Receptor 4 in Diffuse Large B Cell Lymphoma: Achievements and Challenges
}

\author{
Hui Du Lei Gao Jing Luan Hangfan Zhang Taiwu Xiao \\ Division of Hematology, Liaocheng People's Hospital, Liaocheng, PR China
}

\section{Keywords}

Diffuse large B cell lymphoma · C-X-C chemokine receptor 4 - CXCL12/CXCR4 axis · Functional mechanism . Therapeutic applications

\begin{abstract}
Diffuse large B cell lymphoma (DLBCL), an aggressive cancer of the $B$ cells, is the most common subtype of non-Hodgkin lymphoma (NHL) worldwide. In China, the cases of DLBCL increase yearly. C-X-C chemokine receptor 4 (CXCR4) has been implicated in the migration and trafficking of malignant $B$ cells in several hematological malignancies, and only a few reports have been published on the role of CXCR4 in the metastasis of DLBCL. This review summarizes the relevant perspectives on the functional mechanism, prognostic significance, and therapeutic applications of the CXCL12/ CXCR4 axis in DLBCL, in particular DLBCL with bone marrow involvement.

(c) 2019 S. Karger AG, Basel
\end{abstract}

\section{Introduction}

Diffuse large B cell lymphoma (DLBCL) is a clinically, morphologically, and molecularly heterogeneous disease with an unknown etiology, and it accounts for approxi- mately $30 \%$ of adult non-Hodgkin lymphoma (NHL) cases [1-5]. It presents with rapid tumor growth as a nodal or extranodal mass. Approximately $70 \%$ of DLBCL patients have at least 1 extranodal site and $30 \%$ of patients have multiple sites [6]. Overall survival (OS) has improved significantly since the new therapy anti-CD20 monoclonal antibody (rituximab), in combination with $\mathrm{CHOP}$ (cyclophosphamide, vincristine, doxorubicin, and prednisone) chemotherapy, has been in use [7]. Nevertheless, one-third of patients are still refractory or experience a relapse, and most of these patients have poor longterm outcomes $[8,9]$. Therefore, it is necessary to identify the patient groups at diagnosis.

According to the cell of origin, gene expression profiling (GEP) divides DLBCL into activated B cell (ABC) and germinal-center B-like (GCB) subtypes, with approximately $10-20 \%$ of cases being unclassifiable [10]. The prognosis for the GCB subtype is better than for the nonGCB subtype. Because GEP is not widely available, immunohistochemistry (IHC) is used as a substitute to predict the cell of origin. At least 5 IHC-based algorithms are available in daily diagnostic practice [11]. The Hans algorithm, consisting of CD10, BCL-6, and MUM-1(IRF4), is most commonly used. The GCB tumor cells are $\mathrm{CD} 10^{+}$or CD $10^{-} / \mathrm{BCL}^{-} 6^{+} / \mathrm{MUM}^{-} 1^{-}$, and non-GCB tumor cells are $\mathrm{CD} 10^{-} / \mathrm{MUM}^{-1}{ }^{+}[12]$. In the newly revised WHO classification, the adequate IHC panel consists of CD20, CD10,

\section{KARGER}

(C) 2019 S. Karger AG, Basel

E-Mail karger@karger.com

www.karger.com/aha
Hui Du

Division of Hematology, Liaocheng People's Hospital

67 Dongchangxi Road

Liaocheng, Shandong 252000 (PR China)

E-Mail jiuweitutu@163.com 
BCL-6, and MUM-1. The modifications also state that the expression of CD5 and double expressor (MYC and BCL-2) in DLBCL appear to have adverse prognostic value [13]. Schmitz et al. [14] studied 574 DLBCL biopsy samples and extended these findings. They uncovered 4 subtypes of DLBCL, termed MCD (based on the co-occurrence of MYD88L265P and CD79B mutations), BN2 (based on BCL6 fusions and $\mathrm{NOTCH} 2$ mutations), N1 (based on NOTCH1 mutations), and EZB (based on EZH2 mutations and BCL2 translocations). These subtypes with distinct genotypic, epigenetic, and clinical characteristics provided a potential nosology for precision-medicine strategies in DLBCL. The BN2 and EZB subtypes have favorable survival and the MCD and N1 subtypes own the inferior outcomes.

Since the International Prognostic Index (IPI) was developed as a predictive model almost 20 years ago, it has been widely used to predict the outcomes of DLBCL patients [15]. The IPI mainly emphasizes clinical and biological characteristics, such as patient age and tumor stage, but provides little insight into the underlying biologic behavior associated with genetic and molecular variation. Novel biological biomarkers involved in cell signaling and trafficking are necessary [16].

Chemokines surrounding the tumor microenvironment play crucial roles in tumor development by binding to corresponding receptors. They control lymphoid cell development, differentiation, and migration; support B cell development, growth, and survival; and adjust the balance between subsets of $\mathrm{T}$ cells $[17,18]$. The chemokines participate in organogenesis and immune responses, function as cellular growth factors, and facilitate angiogenesis [19]. In addition, they can activate adhesion molecules, which promote the trafficking of lymphocytes into and within tissues $[20,21]$. C-X-C chemokine receptor 4 (CXCR4) is a receptor specific to stromal-derived factor-1 (SDF-1, also CXCL12) [22]. The CXCL12/ CXCR4 axis regulates the migration of $\mathrm{T}$ lymphocytes and other immune cells expressing CXCR4, the retention of $\mathrm{B}$ cell precursors in bone marrow (BM), and the homing of B lymphocytes to lymph nodes [23]. Abnormal CXCR4 expression has been shown to be critical for metastasis to organs with a high expression of CXCL12, such as the BM, lymph nodes, and bones [24], and it has prognostic significance in some solid cancers, such as lung [25], renal [26], prostate [27], breast [28], colorectal [29], and hepatocellular [30] cancers. CXCR4 may also be an indicator of metastasis in several hematological malignancies [31]. CXCR4 overexpression has been associated with poor prognosis and contributes to therapeutic resis-

Research Progress of CXCR4 Expression in DLBCL tance in acute myelogenous leukemia (AML) [32-35], acute lymphoblastic leukemia (ALL) [36, 37], myelodysplastic syndrome (MDS) [38], lymphoplasmacytic lymphoma [39], chronic lymphocytic leukemia (CLL) [40], and other B cell NHLs $[41,42]$. For example, CXCR4 can protect leukemic cells from chemotherapy-induced apoptosis by giving leukemic blasts a higher capacity to seed into $\mathrm{BM}$ niches $[24,32,34,39,43]$.

\section{The CXCL12/CXCR4 Axis and DLBCL}

\section{Cellular Localization of CXCR4}

Lemma et al. [44] and Jahnke et al. [45] found that expression of CXCR4 was localized to the nucleus or cytoplasm of lymphoma cells in primary central nervous system lymphoma samples. Strong nuclear expression of CXCR4 is most strongly associated with nodal DLBCL.

\section{Prognostic Significance of the CXCL12/CXCR4 Axis}

The prognostic significance and functional mechanism of CXCR4 expression in malignant lymphomas is not fully understood. Compared to other types of tumors, primary lymphomas have differing gradients of CXCL12 expression [46]. Few studies have been done on the role of CXCR4 in DLBCL. Some studies determined that the key role of CXCR4 is the dissemination of DLBCL. For example, CXCR4 expression was associated with disease progression in 12 cases of primary testicular DLBCL [47] and 94 cases of DLBCL treated with rituximab-containing regimens [48]. Recently, high CXCR4 expression was reported to be associated with a lower survival rate in mice injected intravenously with DLBCL cells [48]. Another important study showed poorer progression-free survival in a training/validation cohort of 468/275 GCBDLBCL patients due to CXCR4-related chemotaxis [49]. However, in 1 Asian study, CXCR4 was not associated with the survival of DLBCL patients [50].

\section{CXCL12/CXCR4 Axis and BM Infiltration}

Early on, scientists recognized that activated B cells likely home to the BM via CXCR4-dependent pathways during the humoral immune response [51]. CXCR4 expression was found to be linked to BM infiltration in some $B$ cell neoplasms [52]. A positive correlation between a significant decrease in CXCR4 mRNA expression in the $\mathrm{BM}$ after treatment and better prognosis was found in 20 NHL patients [53]. The CXCL12/CXCR4 axis directs CXCR4-positive lymphoma cells to reside in the BM through concentration gradients of CXCL12 and underlies de- 


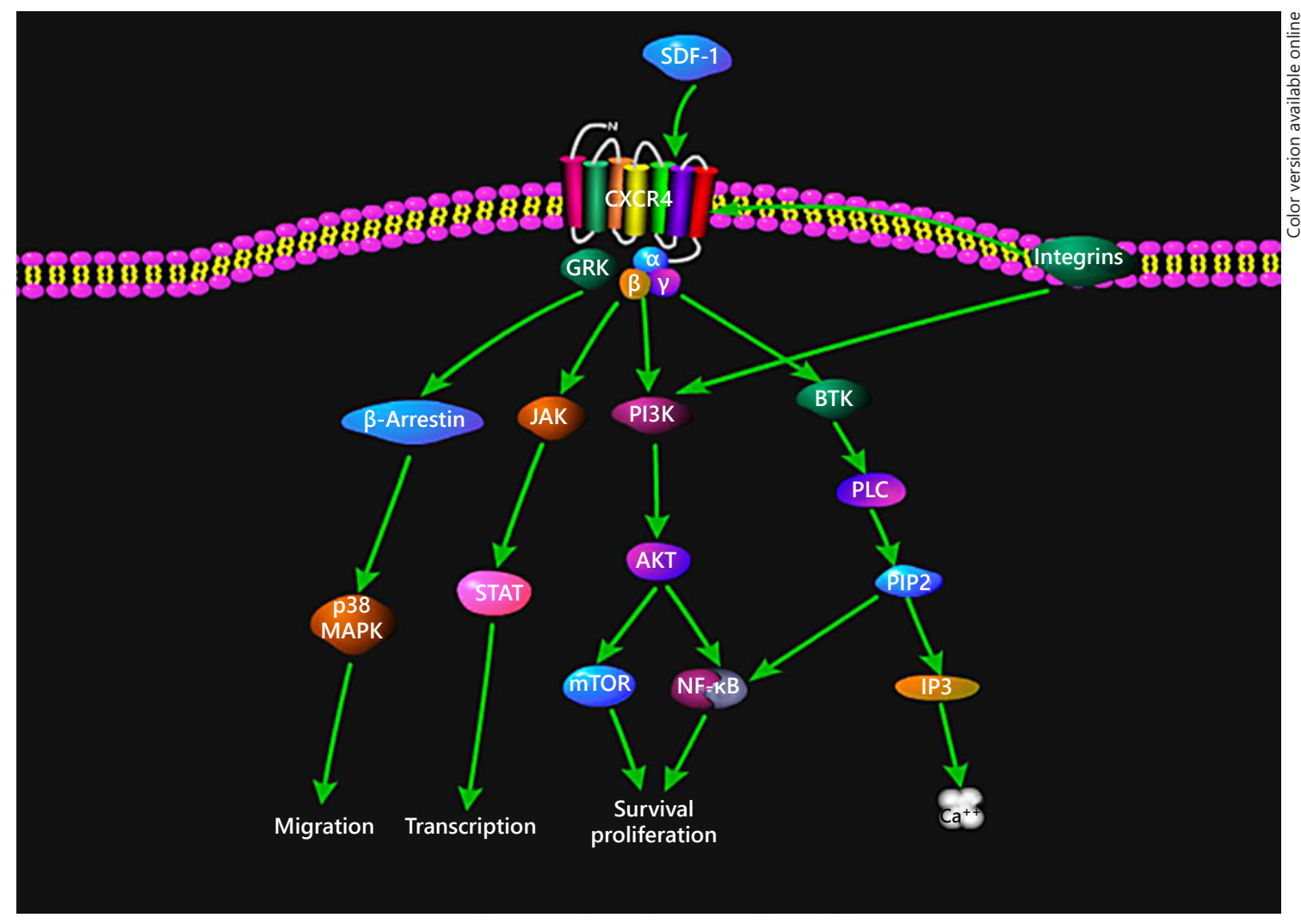

Fig. 1. Schematic diagram of the SDF-1/CXCR4 axis affecting major signaling pathways. SDF-1 (CXCL12) binding to CXCR4 can (1) activate GRK and downstream molecule $\beta$-arrestin, subsequently mediating MAPK signaling promoting cell migration; (2) trigger intracellular calcium mobilization through the activation of the PLC/IP3 signaling pathway; (3) affect the PI3K/AKT signaling pathway. AKT is a central node in signaling cascades that can activate mTOR and NF- $\mathrm{mB}$ regulating cell survival and prolifera- tion; (4) activate JAK/STAT pathway mediating transcription. GRK, G-protein-coupled receptor kinase; MAPK, mitogen-activated protein kinase; BTK, Bruton tyrosine kinase; PLC, phospholipase C; PIP2, phosphatidylinositol 4,5-bisphosphate; IP3, inositol 1,4,5 trisphosphate; PI3K, phosphoinositide-3 kinase; AKT, protein kinase $\mathrm{B}$; mTOR, mammalian target of rapamycin; NF- $\kappa \mathrm{B}$, nuclear factor- $\kappa \mathrm{B}$; JAK, Janus kinase; STAT, signal transducer and activator of transcription. creased chemosensitivity and disease progression. Chen et al. [49] found an inverse correlation between CXCR4 and CXCL12 mRNA expression in the stromal cells of patients without BM involvement. They speculated that this abnormal condition (high CXCR4/low CXCL12) at the primary sites led to the metastasis of CXCR4-positive lymphoma cells to other organs with a higher expression of CXCL12, which directly resulted in the disease progression of DLBCL. Additionally, they found that CXCR4 expression had a significant prognostic effect in nodal but not in extranodal DLBCL.

\section{Functional Mechanisms of CXCR4}

Migration of CXCR4-positive hematopoietic cells is promoted by a CXCL12 gradient produced by stromal cells [54]. Inhibiting the interaction of CXCR4 with
CXCL12 can reverse the tumor-promoting signals of stromal cells, which results in tumor cells being more susceptible to chemotherapy and having an increased rate of apoptosis $[55,56]$. The progression of B-NHL depends partly on interactions with the tumor microenvironment, which are adjusted by integrins, chemokines, and chemokine receptors [57]. There is a feedback loop between CXCL12/CXCR4 and the signaling pathways mediating tumorigenicity. The CXCL12/CXCR4 axis can activate various intracellular signaling transduction pathways and downstream effectors, such as integrin, tyrosine kinases, G-proteins, phosphoinositide 3-kinase (PI3K)/protein kinase B (Akt), mitogen-activated protein kinase (MAPK) pathways, and mammalian target of rapamycin (mTOR) (Fig. 1) [23, 24, 40, 58-61]. Previous studies have confirmed that abnormal activation of the PI3K/Akt/mTOR 
signaling pathway increases tumor proliferation and is associated with the poorer prognosis of patients with DLBCL $[62,63]$. Signaling molecules, physiological stimuli, and cotranslational modifications effect the expression of CXCR4 [49]. CXCR4 expression is positively regulated by nuclear factor (NF)- $\mathrm{kB}, \mathrm{CD} 63$, interleukin (IL)-21, PI3K/Akt, hypoxia-inducible factor 1 a, CREB3, PAX3-FKHR, Wnt, Notch, and the Janus kinase (JAK)/ signal transducer and activator of transcription (STAT) pathways $[49,64,65]$. In contrast, CXCR4 expression is negatively affected by $\mathrm{p} 53$, tumor necrosis factor (TNF)- $\alpha$, interferon (IFN)- $\gamma$, and ubiquitination [24, 58, 66-68].

Let us review the relationship between CXCR4 and NF-kB further. Okera et al. [69] suggested that CXCR4 expression is associated with the activities of IL-8, matrix metalloproteinase (MMP)-9, and vascular endothelial growth factor (VEGF), which are often regulated by NF- $\kappa B$. In a recent study, Shin et al. [50] reported coexpression of NF- $\kappa B$ and CXCR4 in DLBCL patients. In $A B C-D L B C L$, the NF- $\kappa B$ signaling pathway is activated due to mutations in the genes encoding pathway members upstream of NF- $\mathrm{KB}$ [70]. As a central transcription factor, NF- $\mathrm{kB}$ can induce the transcription of CXCR4, and activity of the CXCR4 pathway leads to nuclear accumulation of NF- $\mathrm{BB}[24,71]$. Given the associations between the expression of CXCR4 and NF- $\kappa B$, plerixafor, a CXCR4 antagonist, could possibly counterbalance NF- $\kappa \mathrm{B}$ signaling pathway deregulation.

Furthermore, due to oncogenic elements such as dysregulated TNF cytokines, MYC overexpression, or the secondary event of BCL2 translocation in the germinal center, abnormal reduction in CXCL12 expression in lymph nodes can initiate tumorigenesis [49]. Decreased expression of CXCL12 also leads to the dissemination of CXCR4-positive tumor cells to distant organs with higher CXCL12 levels [46, 72]. Therefore, the levels of CXCL12 and CXCR4 may be highly relevant for both lymphomagenesis and the progression of lymphoma.

\section{Therapeutic Applications}

Since the microenvironment provides growth and survival stimuli for both normal [73] and neoplastic lymphocytes [74-76], understanding the environmental niches of the neoplastic cells in B-NHL can lead to new therapeutic approaches. Some drugs, such as ibrutinib (a Bruton tyrosine kinase inhibitor) and idelalisib (a PI3K inhibitor), have been successfully used in the treatment of lymphoma [77-79]. These drugs inhibit the kinases involved in $\mathrm{B}$ cell receptor signaling and displace B-NHL cells from their protective residencies by block- ing chemokine-induced adhesion signals [80]. In a similar way, inhibitors of CXCR4 have been shown to enhance the efficacy of rituximab in the B-NHL mouse model [81].

Inhibiting the interactions of CXCL12 and CXCR4 can disrupt metastasis, promote apoptosis, and increase the chemosensitivity of a variety of cancers [82-84]. Therapeutic regimens containing a CXCR4 antagonist can increase the rate of cell death in lymphoma models [85]. The effects of CXCR4 antagonists, in combination with traditional antineoplastic agents, are being evaluated in clinical trials for the treatment of hematological malignancies [86]. For example, the CXCR4 antagonist plerixafor has been found to enhance the effect of rituximab in Burkitt's lymphoma [87, 88]. Plerixafor, a bicyclic reversible inhibitor, blocks the binding of CXCL12 to CXCR4 by combining with an extracellular binding pocket [86]. It can prevent tumor cell homing to $\mathrm{BM}$ and mobilize the cells to the peripheral blood, which may cause the tumor cells with CXCR4 overexpression to be more susceptible to treatment with rituximab [89]. The effect of plerixafor occurs via receptor blockade or by disrupting the tumorstromal cell mutual effect, thereby preventing stroma-induced CXCR4 expression. O'Callaghan et al. [87] found that combining plerixafor with rituximab in vivo significantly prolonged the survival time of mice with Burkitt's lymphoma and CLL. In contrast, low doses $(10 \mu \mathrm{M})$ of plerixafor did not significantly increase the survival of Burkitt's lymphoma cells in vitro. As such, the effect of plerixafor on the proliferating tumor cells is believed to be greatly dependent on the drug concentration. Other studies found that plerixafor can significantly enhance the effect of rituximab at most drug concentrations [90]. From these findings, a synergistic interaction between rituximab and plerixafor can be inferred. Cell-penetrating lipopeptide pepducins and the CXCR4 antagonist BKT140 have an enhancing effect on rituximab efficacy as well [81]. BKT140 can reverse rituximab-induced cellular arrest in Burkitt's lymphoma by increasing the activation of the apoptotic caspase 3 pathway. CXCR4 antagonists have also been shown to enhance the effect of other drugs in the R-CHOP regimen. Lee et al. [91] verified a synergistic drug interaction of the CXCR4 antagonist T22 and cyclophosphamide in vivo. In ALL, the survival time of engrafted mice was extended with a combination of the drugs plerixafor and vincristine [92]. Adding a CXCR4 antagonist to the therapeutic schedule can reduce the cycles of chemotherapy that a patient must receive, which may increase the curative effect or lower the drug-induced toxicity [93]. 


\section{Conclusion and Perspectives}

The expression of CXCR4 plays a crucial role in the oncogenesis and tumor progression of DLBCL. The potential related mechanisms need to be further elucidated. CXCR4 is associated with poor survival and could be used as a prognostic marker for DLBCL. The CXCL12/CXCR4 axis may prove to be a novel therapeutic target for reducing metastasis in DLBCL.

\section{Statement of Ethics}

The authors have no ethical conflicts to disclose.

\section{Disclosure Statement}

All authors declare that they have no conflicts of interest.

\section{Funding Sources}

There was no funding.

\section{Author Contributions}

The manuscript was written through contributions of all authors. All authors have given approval to the final version.

\section{References}

1 Armitage J. A clinical evaluation of the international lymphoma study group classification of non-Hodgkin' lymphoma by the nonHodgkin' lymphoma classification project. Blood. 1997;89:3909-18.

2 Kumar V, Abbas A, Fausto N, Aster J, editors. Robbins and Cotran Pathologic Basis of Disease. 8th ed. Oxford: Elsevier; 2009. p. 607.

3 Swerdlow S, Campo E, Harris NL. WHO Classification of Tumours of Haematopoietic and Lymphoid Tissues. Lyon: IARC Press; 2008.

4 Friedberg JW, Fisher RI. Diffuse large B-cell lymphoma. Hematol Oncol Clin North Am. 2008 Oct;22(5):941-52.

5 Wu L, Ehlin-Henriksson B, Zhou X, et al. EBV provides survival factors to EBV+ DLBCL lines and modulates cytokine induced specific chemotaxis in EBV+ DLBCL. Immunology. 2017;152(4):562-73.

6 Hui D, Proctor B, Donaldson J, Shenkier T, Hoskins P, Klasa R, et al. Prognostic implications of extranodal involvement in patients with diffuse large B-cell lymphoma treated with rituximab and cyclophosphamide, doxorubicin, vincristine, and prednisone. Leuk Lymphoma. 2010 Sep;51(9):1658-67.

7 Cultrera JL, Dalia SM. Diffuse large B-cell lymphoma: current strategies and future directions. Cancer Contr. 2012 Jul;19(3):204-13.

8 Friedberg JW. Relapsed/refractory diffuse large B-cell lymphoma. Hematology (Am Soc Hematol Educ Program). 2011;2011(1):498505.

9 Cai Q, Westin J, Fu K, Desai M, Zhang L, Huang $\mathrm{H}$, et al. Accelerated therapeutic progress in diffuse large B cell lymphoma. Ann Hematol. 2014 Apr;93(4):541-56.

10 Alizadeh AA, Eisen MB, Davis RE, Ma C, Lossos IS, Rosenwald A, et al. Distinct types of diffuse large B-cell lymphoma identified by gene expression profiling. Nature. 2000 Feb; 403(6769):503-11.
11 Meyer PN, Fu K, Greiner TC, Smith LM, Delabie J, Gascoyne RD, et al. Immunohistochemical methods for predicting cell of origin and survival in patients with diffuse large Bcell lymphoma treated with rituximab. J Clin Oncol. 2011 Jan;29(2):200-7.

12 Hans CP, Weisenburger DD, Greiner TC, Gascoyne RD, Delabie J, Ott G, et al. Confirmation of the molecular classification of diffuse large B-cell lymphoma by immunohistochemistry using a tissue microarray. Blood. 2004 Jan;103(1):275-82.

13 Swerdlow SH, Campo E, Pileri SA, Harris NL, Stein H, Siebert R, et al. The 2016 revision of the World Health Organization classification of lymphoid neoplasms. Blood. 2016 May; 127(20):2375-90.

14 Schmitz R, Wright GW, Huang DW, Johnson CA, Phelan JD, Wang JQ, et al. Genetics and Pathogenesis of Diffuse Large B-Cell Lymphoma. NEngl J Med. 2018 Apr;378(15):1396-407.

15 Ghielmini M, Vitolo U, Kimby E, Montoto S, Walewski J, Pfreundschuh M, et al.; Panel Members of the 1st ESMO Consensus Conference on Malignant Lymphoma. ESMO Guidelines consensus conference on malignant lymphoma 2011 part 1: diffuse large Bcell lymphoma (DLBCL), follicular lympho$\mathrm{ma}(\mathrm{FL})$ and chronic lymphocytic leukemia (CLL). Ann Oncol. 2013 Mar;24(3):561-76.

16 Perry AM, Mitrovic Z, Chan WC. Biological prognostic markers in diffuse large B-cell lymphoma. Cancer Contr. 2012 Jul;19(3): 214-26.

17 Acosta-Rodríguez E V, Merino M C, Montes $\mathrm{C}$ L, et al. Cytokines and chemokines shaping the B-cell compartment. Cytokine Growth Factor Rev. 2007;18(1):73-83

18 Zwirner NW, Domaica CI. Cytokine regulation of natural killer cell effector functions. Biofactors. 2010 Jul-Aug;36(4):274-88.

19 Zlotnik A, Burkhardt AM, Homey B. Homeostatic chemokine receptors and organ-specif- ic metastasis. Nat Rev Immunol. 2011 Aug; 11(9):597-606

20 Fu L, Li ZJ, Yang GL, Zheng JF, Shi QZ, Chen SJ, et al. RNAi-mediated Silencing of CXCR4 Inhibits the Adhesion, Invasion and Tumorigenicity of Acute Monocytic Leukemic Cell Line SHI-1. Zhongguo Shi Yan Xue Ye Xue Za Zhi. 2015 Oct;23(5):1286-91. Chinese.

21 Chatterjee S, Behnam Azad B, Nimmagadda $\mathrm{S}$. The intricate role of CXCR4 in cancer. Ady Cancer Res. 2014;124(2):31-82.

22 Zhao H, Guo L, Zhao H, Zhao J, Weng H, Zhao B. CXCR4 over-expression and survival in cancer: a system review and meta-analysis. Oncotarget. 2015 Mar;6(7):5022-40.

23 Kallikourdis M, Trovato AE, Anselmi F, Sarukhan A, Roselli G, Tassone L, et al. The CXCR4 mutations in WHIM syndrome impair the stability of the T-cell immunologic synapse. Blood. 2013 Aug;122(5):66673.

24 Cojoc M, Peitzsch C, Trautmann F, Polishchuk L, Telegeev GD, Dubrovska A. Emerging targets in cancer management: role of the CXCL12/CXCR4 axis. Onco Targets Ther. 2013 Sep;6:1347-61.

25 Katsura M, Shoji F, Okamoto T, Shimamatsu S, Hirai F, Toyokawa G, et al. Correlation between CXCR4/CXCR7/CXCL12 chemokine axis expression and prognosis in lymphnode-positive lung cancer patients. Cancer Sci. 2018 Jan;109(1):154-65.

26 Rasti A, Abolhasani M, Zanjani LS, Asgari M, Mehrazma M, Madjd Z. Reduced expression of CXCR4, a novel renal cancer stem cell marker, is associated with high-grade renal cell carcinoma. J Cancer Res Clin Oncol. 2017 Jan;143(1):95-104

27 Conley-LaComb MK, Semaan L, Singareddy R, Li Y, Heath EI, Kim S, et al. Pharmacological targeting of CXCL12/CXCR4 signaling in prostate cancer bone metastasis. Mol Cancer. 2016 Nov; 15(1):68. 
28 Chittasupho C, Anuchapreeda S, Sarisuta N. CXCR4 targeted dendrimer for anti-cancer drug delivery and breast cancer cell migration inhibition. Eur J Pharm Biopharm. 2017 Oct; 119:310-21.

29 Weixler B, Renetseder F, Facile I, Tosti N, Cremonesi E, Tampakis A, et al. Phosphorylated CXCR4 expression has a positive prognostic impact in colorectal cancer. Cell Oncol (Dordr). 2017 Dec;40(6):609-19.

30 Kaemmerer D, Schindler R, Mußbach F, et al. Somatostatin and CXCR4 chemokine receptor expression in hepatocellular and cholangiocellular carcinomas: tumor capillaries as promising targets. BMC Cancer. 2017;17(1): 896.

31 Calandra G, Bridger G, Fricker S. CXCR4 in clinical hematology. Curr Top Microbiol Immunol. 2010;341:173-91.

32 Sison EA, McIntyre E, Magoon D, Brown P. Dynamic chemotherapy-induced upregulation of CXCR4 expression: a mechanism of therapeutic resistance in pediatric AML. Mol Cancer Res. 2013 Sep;11(9):1004-16.

33 Chen Y, Jacamo R, Konopleva M, Garzon R, Croce C, Andreeff M. CXCR4 downregulation of let-7a drives chemoresistance in acute myeloid leukemia. J Clin Invest. 2013 Jun; 123(6):2395-407.

34 Brault L, Rovó A, Decker S, Dierks C, Tzankov A, Schwaller J. CXCR4-SERINE339 regulates cellular adhesion, retention and mobilization, and is a marker for poor prognosis in acute myeloid leukemia. Leukemia. 2014 Mar; 28(3):566-76

35 Ahn JY, Seo K, Weinberg OK, Arber DA. The prognostic value of CXCR4 in acute myeloid leukemia. Appl Immunohistochem Mol Morphol. 2013 Jan;21(1):79-84.

36 de Lourdes Perim A, Amarante MK, Guembarovski RL, de Oliveira CE, Watanabe MA. CXCL12/CXCR4 axis in the pathogenesis of acute lymphoblastic leukemia (ALL): a possible therapeutic target. Cell Mol Life Sci. 2015 May;72(9):1715-23.

37 Zhang Y, Guo Q, Zhao H, Zhao D, Wu X, Zhao W, et al. Expression of CXCR4 is an independent prognostic factor for overall survival and progression-free survival in patients with myelodysplastic syndrome. Med Oncol. 2013 Mar;30(1):341.

38 Schmidt J, Federmann B, Schindler N, Steinhilber J, Bonzheim I, Fend F, et al. MYD88 L265P and CXCR4 mutations in lymphoplasmacytic lymphoma identify cases with high disease activity. Br J Haematol. 2015 Jun, 169(6):795-803.

39 Han TT, Fan L, Li JY, Xu W. Role of chemokines and their receptors in chronic lymphocytic leukemia: function in microenvironment and targeted therapy. Cancer Biol Ther. 2014 Jan;15(1):3-9.

40 Middle S, Coupland SE, Taktak A, Kidgell V, Slupsky JR, Pettitt AR, et al. Immunohistochemical analysis indicates that the anatomical location of B-cell non-Hodgkin's lympho$\mathrm{ma}$ is determined by differentially expressed chemokine receptors, sphingosine-1-phosphate receptors and integrins. Exp Hematol Oncol. 2015 Apr;4(1):10.

41 Kim YR, Eom KS. Simultaneous inhibition of CXCR4 and VLA-4 exhibits combinatorial effect in overcoming stroma-mediated chemotherapy resistance in mantle cell lymphoma cells. Immune Netw. 2014 Dec;14(6):296-306.

42 Zeng Z, Shi YX, Samudio IJ, Wang RY, Ling $\mathrm{X}$, Frolova $\mathrm{O}$, et al. Targeting the leukemia microenvironment by CXCR4 inhibition overcomes resistance to kinase inhibitors and chemotherapy in AML. Blood. 2009 Jun;113(24): 6215-24.

43 Ko SY, Park CJ, Park SH, Cho YU, Jang S, Seo EJ, et al. High CXCR4 and low VLA-4 expression predicts poor survival in adults with acute lymphoblastic leukemia. Leuk Res. 2014 Jan;38(1):65-70.

44 Lemma SA, Pasanen AK, Haapasaari KM, Sippola A, Sormunen R, Soini Y, et al. Similar chemokine receptor profiles in lymphomas with central nervous system involvement possible biomarkers for patient selection for central nervous system prophylaxis, a retrospective study. Eur J Haematol. 2016 May; 96(5):492-501.

45 Jahnke K, Coupland SE, Na IK, Loddenkemper C, Keilholz U, Korfel A, et al. Expression of the chemokine receptors CXCR4, CXCR5, and CCR7 in primary central nervous system lymphoma. Blood. 2005 Jul;106(1):384-5.

46 Roy I, Evans DB, Dwinell MB. Chemokines and chemokine receptors: update on utility and challenges for the clinician. Surgery. 2014 Jun;155(6):961-73.

47 Menter T, Ernst M, Drachneris J, Dirnhofer S, Barghorn A, Went $\mathrm{P}$, et al. Phenotype profiling of primary testicular diffuse large B-cell lymphomas. Hematol Oncol. 2014 Jun;32(2): 72-81.

48 Moreno MJ, Bosch R, Dieguez-Gonzalez R, Novelli S, Mozos A, Gallardo A, et al. CXCR4 expression enhances diffuse large B cell lymphoma dissemination and decreases patient survival. J Pathol. 2015 Feb;235(3):445-55.

49 Chen J, Xu-Monette ZY, Deng L, Shen Q, Manyam GC, Martinez-Lopez A, et al. Dysregulated CXCR4 expression promotes lymphoma cell survival and independently predicts disease progression in germinal center B-cell-like diffuse large B-cell lymphoma. Oncotarget. 2015 Mar;6(8):5597-614.

50 Shin HC, Seo J, Kang BW, Moon JH, Chae YS, Lee SJ, et al. Clinical significance of nuclear factor $\mathrm{\kappa B}$ and chemokine receptor CXCR $4 \mathrm{ex}$ pression in patients with diffuse large B-cell lymphoma who received rituximab-based therapy. Korean J Intern Med (Korean Assoc Intern Med). 2014 Nov;29(6):785-92.

51 Stein JV, Nombela-Arrieta C. Chemokine control of lymphocyte trafficking: a general overview. Immunology. 2005 Sep;116(1):1-12.

52 Deutsch AJ, Steinbauer E, Hofmann NA, Strunk D, Gerlza T, Beham-Schmid C, et al. Chemokine receptors in gastric MALT lymphoma: loss of CXCR4 and upregulation of
CXCR7 is associated with progression to diffuse large B-cell lymphoma. Mod Pathol. 2013 Feb;26(2):182-94.

53 Mazur G, Butrym A, Kryczek I, Dlubek D, Jaskula E, Lange A, et al. Decreased expression of CXCR4 chemokine receptor in bone marrow after chemotherapy in patients with non-Hodgkin lymphomas is a good prognostic factor. PLoS One. 2014 May;9(5):e98194.

54 Burger JA, Kipps TJ. CXCR4: a key receptor in the crosstalk between tumor cells and their microenvironment. Blood. 2006 Mar;107(5): 1761-7.

55 Azab AK, Runnels JM, Pitsillides C, Moreau AS, Azab F, Leleu X, et al. CXCR4 inhibitor AMD3100 disrupts the interaction of multiple myeloma cells with the bone marrow microenvironment and enhances their sensitivity to therapy. Blood. 2009 Apr;113(18):434151.

56 Kurtova AV, Tamayo AT, Ford RJ, Burger JA Mantle cell lymphoma cells express high levels of CXCR4, CXCR5, and VLA-4 (CD49d): importance for interactions with the stromal microenvironment and specific targeting. Blood. 2009 May;113(19):4604-13.

57 Coupland SE. The challenge of the microenvironment in B-cell lymphomas. Histopathology. 2011 Jan;58(1):69-80.

58 Busillo JM, Benovic JL. Regulation of CXCR4 signaling. Biochim Biophys Acta. 2007 Apr; 1768(4):952-63.

59 Majchrzak A, Witkowska M, Smolewski P. Inhibition of the PI3K/Akt/mTOR signaling pathway in diffuse large B-cell lymphoma: current knowledge and clinical significance. Molecules. 2014 Sep;19(9):14304-15.

60 Xu ZZ, Shen JK, Zhao SQ, Li JM. Clinical significance of chemokine receptor CXCR4 and mammalian target of rapamycin (mTOR) expression in patients with diffuse large B-cell lymphoma. Leuk Lymphoma. 2018 Jun;59(6): 1451-60.

61 Wang Y, Zhang M, Xu H, Wang Y, Li Z, Chang $Y$, et al. Discovery and validation of the tumor-suppressive function of long noncoding RNA PANDA in human diffuse large Bcell lymphoma through the inactivation of MAPK/ERK signaling pathway. Oncotarget. 2017 Aug;8(42):72182-96.

62 Xu ZZ, Xia ZG, Wang AH, Wang WF, Liu ZY, Chen LY, et al. Activation of the PI3K/AKT/ mTOR pathway in diffuse large B cell lymphoma: clinical significance and inhibitory effect of rituximab. Ann Hematol. 2013 Oct 92(10):1351-8.

63 Camicia R, Winkler HC, Hassa PO. Novel drug targets for personalized precision medicine in relapsed/refractory diffuse large B-cell lymphoma: a comprehensive review. Mol Cancer. 2015 Dec;14(1):207.

64 Peng SB, Peek V, Zhai Y, Paul DC, Lou Q, Xia $\mathrm{X}$, et al. Akt activation, but not extracellular signal-regulated kinase activation, is required for SDF-1alpha/CXCR4-mediated migration of epitheloid carcinoma cells. Mol Cancer Res. 2005 Apr;3(4):227-36. 
65 Han Y, He T, Huang DR, Pardo CA, Ransohoff RM. TNF-alpha mediates SDF-1 alphainduced NF-kappa B activation and cytotoxic effects in primary astrocytes. J Clin Invest. 2001 Aug;108(3):425-35.

66 Mehta SA, Christopherson KW, BhatNakshatri P, Goulet RJ Jr, Broxmeyer HE, Kopelovich L, et al. Negative regulation of chemokine receptor CXCR4 by tumor suppressor p53 in breast cancer cells: implications of p53 mutation or isoform expression on breast cancer cell invasion. Oncogene. 2007 May; 26(23):3329-37.

67 Yoshida N, Kitayama D, Arima M, Sakamoto $\mathrm{A}$, Inamine $\mathrm{A}$, Watanabe-Takano $\mathrm{H}$, et al. CXCR4 expression on activated B cells is downregulated by CD63 and IL-21. J Immunol. 2011 Mar;186(5):2800-8.

68 Brühl H, Cohen CD, Linder S, Kretzler M, Schlöndorff D, Mack M. Post-translational and cell type-specific regulation of CXCR4 expression by cytokines. Eur J Immunol. 2003 Nov;33(11):3028-37.

69 Okera M, Bae K, Bernstein E, Cheng L, Lawton $\mathrm{C}$, Wolkov $\mathrm{H}$, et al. Evaluation of nuclear factor $\mathrm{\kappa B}$ and chemokine receptor CXCR4 coexpression in patients with prostate cancer in the Radiation Therapy Oncology Group (RTOG) 8610. BJU Int. 2011 Jul;108(2 Pt 2): E51-8.

70 Lenz G. Insights into the Molecular Pathogenesis of Activated B-Cell-like Diffuse Large BCell Lymphoma and Its Therapeutic Implications. Cancers (Basel). 2015 May;7(2):811-22.

71 Es-Haghi M, Soltanian S, Dehghani H. Perspective: cooperation of Nanog, NF- $\mathrm{BB}$, and CXCR4 in a regulatory network for directed migration of cancer stem cells. Tumour Biol. 2016 Feb;37(2):1559-65.

72 Young KH, Medeiros LJ, Chan WC. Diffuse large B-cell lymphoma. In: Orazi A, Weiss LM, Foucar K, Knowles DM, editors. Neoplastic Hematopathology. Philadelphia, PA, USA: Lippincott Willaims \& Wilkins; 2014. pp. 502-65.

73 Förster R, Schubel A, Breitfeld D, Kremmer E, Renner-Müller I, Wolf E, et al. CCR7 coordinates the primary immune response by establishing functional microenvironments in secondary lymphoid organs. Cell. 1999 Oct;99(1): 23-33.

74 Burger JA, Ford RJ. The microenvironment in mantle cell lymphoma: cellular and molecular pathways and emerging targeted therapies. Semin Cancer Biol. 2011 Nov;21(5):308-12.

75 Kiaii S, Clear AJ, Ramsay AG, Davies D, Sangaralingam A, Lee A, et al. Follicular lymphoma cells induce changes in T-cell gene expression and function: potential impact on survival and risk of transformation. J Clin Oncol. 2013 Jul;31(21):2654-61.

76 Medina DJ, Goodell L, Glod J, Gélinas C, Rabson $\mathrm{AB}$, Strair RK. Mesenchymal stromal cells protect mantle cell lymphoma cells from spontaneous and drug-induced apoptosis through secretion of B-cell activating factor and activation of the canonical and non-canonical nuclear factor $\kappa \mathrm{B}$ pathways. Haematologica. 2012 Aug;97(8):1255-63.

77 Gopal AK, Kahl BS, de Vos S, Wagner-Johnston ND, Schuster SJ, Jurczak WJ, et al. PI3K $\delta$ inhibition by idelalisib in patients with relapsed indolent lymphoma. N Engl J Med. 2014 Mar;370(11):1008-18.

78 Advani RH, Buggy JJ, Sharman JP, Smith SM, Boyd TE, Grant B, et al. Bruton tyrosine kinase inhibitor ibrutinib (PCI-32765) has significant activity in patients with relapsed/refractory B-cell malignancies. J Clin Oncol. 2013 Jan;31(1):88-94.

79 Wang ML, Rule S, Martin P, Goy A, Auer R, Kahl BS, et al. Targeting BTK with ibrutinib in relapsed or refractory mantle-cell lymphoma. N Engl J Med. 2013 Aug;369(6):507-16.

80 Chang BY, Francesco M, De Rooij MF, Magadala P, Steggerda SM, Huang MM, et al. Egress of CD19(+)CD5(+) cells into peripheral blood following treatment with the Bruton tyrosine kinase inhibitor ibrutinib in mantle cell lymphoma patients. Blood. 2013 Oct:122(14):2412-24.

81 Beider K, Ribakovsky E, Abraham M, Wald $\mathrm{H}$, Weiss L, Rosenberg E, et al. Targeting the CD20 and CXCR4 pathways in non-hodgkin lymphoma with rituximab and high-affinity CXCR4 antagonist BKT140. Clin Cancer Res. 2013 Jul;19(13):3495-507.

82 Vianello F, Villanova F, Tisato V, Lymperi S, Ho KK, Gomes AR, et al. Bone marrow mesenchymal stromal cells non-selectively protect chronic myeloid leukemia cells from imatinib-induced apoptosis via the CXCR4/ CXCL12 axis. Haematologica. 2010 Jul;95(7): 1081-9.

83 Heckmann D, Maier P, Laufs S, Wenz F, Zeller WJ, Fruehauf S, et al. CXCR4 Expres- sion and Treatment with SDF-1a or Plerixafor Modulate Proliferation and Chemosensitivity of Colon Cancer Cells. Transl Oncol. 2013 Apr;6(2):124-32.

84 Domanska UM, Timmer-Bosscha H, Nagengast WB, Oude Munnink TH, Kruizinga RC, Ananias HJ, et al. CXCR4 inhibition with AMD3100 sensitizes prostate cancer to docetaxel chemotherapy. Neoplasia. 2012 Aug;14(8):709-18.

85 Foon KA, Takeshita K, Zinzani PL. Novel therapies for aggressive B-cell lymphoma. Adv Hematol. 2012;2012:302570.

86 Ramsey DM, McAlpine SR. Halting metastasis through CXCR4 inhibition. Bioorg Med Chem Lett. 2013 Jan;23(1):20-5

87 O'Callaghan K, Lee L, Nguyen N, Hsieh MY, Kaneider NC, Klein AK, et al. Targeting CXCR4 with cell-penetrating pepducins in lymphoma and lymphocytic leukemia. Blood. 2012 Feb;119(7):1717-25.

$88 \mathrm{Hu}$ Y, Gale M, Shields J, Garron C, Swistak M, Nguyen TH, et al. Enhancement of the antitumor activity of therapeutic monoclonal antibodies by CXCR4 antagonists. Leuk Lymphoma. 2012 Jan;53(1):130-8.

89 Burger JA. Disrupting the food chain in B cell lymphomas: co-operation between CXCR4 antagonists and antibodies. Leuk Lymphoma. 2012 Jan;53(1):3-4.

90 Reinholdt L, Laursen MB, Schmitz A, Bødker JS, Jakobsen LH, Bøgsted M, et al. The CXCR4 antagonist plerixafor enhances the effect of rituximab in diffuse large B-cell lymphoma cell lines. Biomark Res. 2016 Jun;4(1):12.

91 Lee $\mathrm{CH}$, Kakinuma T, Wang J, Zhang H, Palmer DC, Restifo NP, et al. Sensitization of B16 tumor cells with a CXCR4 antagonist increases the efficacy of immunotherapy for established lung metastases. Mol Cancer Ther. 2006 Oct;5(10):2592-9.

92 Welschinger R, Liedtke F, Basnett J, Dela Pena A, Juarez JG, Bradstock KF, et al. Plerixafor (AMD3100) induces prolonged mobilization of acute lymphoblastic leukemia cells and increases the proportion of cycling cells in the blood in mice. Exp Hematol. 2013 Mar;41(3): 293-302.e1.

93 Chou TC. Theoretical basis, experimental design, and computerized simulation of synergism and antagonism in drug combination studies. Pharmacol Rev. 2006 Sep;58(3):62181. 